\title{
Impression Management: A Literature Review and Two-Component Model
}

\author{
Mark R. Leary and Robin M. Kowalski \\ Wake Forest University
}

\begin{abstract}
Impression management, the process by which people control the impressions others form of them, plays an important role in interpersonal behavior. This article presents a 2-component model within which the literature regarding impression management is reviewed. This model conceptualizes impression management as being composed of 2 discrete processes. The 1st involves impression motivation-the degree to which people are motivated to control how others see them. Impression motivation is conceptualized as a function of 3 factors: the goal-relevance of the impressions one creates, the value of desired outcomes, and the discrepancy between current and desired images. The 2 nd component involves impression construction. Five factors appear to determine the kinds of impressions people try to construct: the self-concept, desired and undesired identity images, role constraints, target's values, and current social image. The 2-component model provides coherence to the literature in the area, addresses controversial issues, and supplies a framework for future research regarding impression management.
\end{abstract}

People have an ongoing interest in how others perceive and evaluate them. Each year, Americans spend billions of dollars on diets, cosmetics, and plastic surgery-all intended to make them more attractive to others. Political candidates are packaged for the public's consumption like automobiles or breakfast cereals. Parents stress to their children the importance of first impressions and, when trying to control public misbehaviors, may admonish them to consider "what the neighbors will think." Millions of people become paralyzed at the prospect of speaking or performing in public because they are worried about the audience's evaluation of them. Even in relatively mundane encounters at home, work, school, and elsewhere, people monitor others' reactions to them and often try to convey images of themselves that promote their attainment of desired goals.

Impression management (also called self-presentation) refers to the process by which individuals attempt to control the impressions others form of them. Because the impressions people make on others have implications for how others perceive, evaluate, and treat them, as well as for their own views of themselves, people sometimes behave in ways that will create certain impressions in others' eyes.

Although most writers have used the terms impression management and self-presentation interchangeably, some have distinguished between them. Schlenker (1980), for example, defined impression management as the "attempt to control images that are projected in real or imagined social interactions" and reserved the term self-presentation for instances in which the projected images are "self-relevant" (p. 6). Presumably, people may manage the impressions of entities other than them-

Correspondence concerning this article should be addressed to Mark R. Leary, Department of Psychology, Wake Forest University, Post Office Box 7778, Reynolda Station, Winston-Salem, North Carolina 27109 . selves, such as businesses, cities, and other people. Similarly, D. J. Schneider (1981) pointed out that impressions may be managed by means other than self-presentation. For example, impressions of an individual may be managed by a third party. In general, then, impression management is a broader and more encompassing term than self-presentation. However, because most research has dealt with how people control the impressions others form of them (for which both terms are appropriate), we use the terms interchangeably.

Some theorists have suggested that self-presentation involves not only people's attempts to manage the impressions others form, but also efforts to control their impressions of themselves as well (Greenwald \& Breckler, 1985; Hogan, Jones, \& Cheek, 1985; Schlenker, 1985). Although we acknowledge that people are motivated to maintain particular beliefs about themselves (Greenwald \& Breckler, 1985), we dispute that this should be regarded as "self-presentation to the self."

Our conceptualization of self-presentation coincides with those who have defined impression management (or self-presentation) only in terms of fostering impressions in others' eyes (Arkin \& Baumgardner, 1986; Baumeister, 1982b; Baumeister \& Tice, 1986; Goffman, 1959; E. E. Jones \& Pittman, 1982; Schlenker, 1980; D. J. Schneider, 1981; Tedeschi, 1986). The issue is more than semantic. We see conceptual drawbacks to regarding the maintenance of private self-images and the maintenance of public impressions as the same phenomenon (see Tedeschi, 1986).

Most important, the psychological manifestations of these two processes are often quite different. In most instances, the maintenance of private self-perceptions is mediated purely by cognitive processes. In their discussion of this issue, Greenwald and Breckler (1985) described several phenomena that reflect people's interest in maintaining desired private identities, such as self-serving attributions in private settings. However, each of their examples involves purely cognitive processes. To the ex- 
tent that the maintenance of private self-identity often occurs entirely on a cognitive level, any self-relevant thought could potentially be viewed as self-presentation to the self. Public selfpresentation is, of course, always overtly behavioral.

Second, factors that motivate and constrain public impression management and private self-image maintenance differ in many respects. Many of the purely social factors that affect people's public images play little or no role in private self-maintenance. As Tedeschi observed,

secret agendas, a desire to manipulate or deceive others, the goal of getting others to mediate reinforcements that otherwise would not be attainable, as well as possession of different perspectives, information, and values contribute to important differences between the observations and evaluations of one's own behavior and the attributions made by others. $(1986$, p. 10)

Schlenker (1986, p. 23) has provided a potentially useful approach to reconciling the self-as-audience and others-as-audience approaches. He uses the broader term self-identification to refer to the "process, means, or result of showing oneself to be a particular type of person, thereby specifying one's identity" (see also Schlenker, 1985). Defined in this manner, the maintenance of both private self-images and public impressions are subtypes of self-identification. People may engage in self-identification to themselves as well as to others. Schlenker's model provides an important means of integrating conceptual analyses of private and public self-processes, but considerable empirical work is needed to document their differences and similarities. In any case, nothing in Schlenker's model suggests that private and public self-identification processes are isomorphic or indistinguishable.

In this article, our interest is only on factors that affect selfpresentations to others. This is not to deny the fact that private self-motives play a role in impression management (which is discussed later), or the fact that people try to maintain certain views of themselves. However, because virtually all previous work has dealt with self-presentations to others and because we view these two processes as distinct, our review is confined to this literature.

Scientific interest in self-presentation can be traced to Goffman (1959). In his seminal book, The Presentation of Self in Everyday Life, Goffman discussed the importance of selfpresentation for defining the individual's place in the social order, for setting the tone and direction of an interaction, and for facilitating the performance of role-governed behavior. As a sociologist, Goffman was interested primarily in the role that self-presentation plays in the construction of social reality. Furthermore, Goffman tended to dismiss the importance of inner psychological factors in symbolic social interactions in favor of external factors that are "impressed" on the individual from without (1967, p. 45).

E. E. Jones and his colleagues extended self-presentation to include people's attempts to control others' impressions of their personal characteristics and sparked psychologists' interest in impression management (E. E. Jones, 1964; E. E. Jones, Gergen, Gumpert, \& Thibaut, 1965; E. E. Jones, Gergen, \& Jones, 1963). Jones subsequently contributed theoretical perspectives and a great deal of empirical research to the study of self-presentation (e.g., E. E. Jones \& Pittman, 1982; E. E. Jones \& Wortman, 1972).
Despite a steady stream of research during the 1960 s and 1970 s, impression management remained a relatively peripheral topic in social and personality psychology, leading some to characterize the impression management approach as more of a guiding model than a theory of interpersonal behavior (E. E. Jones \& Pittman, 1982; Shaw \& Costanzo, 1982; Tetlock \& Manstead, 1985). Indeed, until quite recently, few textbooks in social psychology devoted more than a passing reference to impression management.

More recently, however, impression management has attracted increased attention as a fundamental interpersonal process. Recent interest in self-presentational processes has been fueled by two developments. First, E. E. Jones and Pittman (1982), Schlenker (1980, 1985), Baumeister (1982b, 1986), Hogan (1982), and others have contributed excellent conceptual analyses of impression management, thereby providing coherence to the area.

In addition, researchers have applied impression management perspectives to an increasing variety of interpersonal phenomena, such as aggression (Felson, 1978; Tedeschi, Smith, \& Brown, 1974), attitude change (Schlenker, Forsyth, Leary, \& Miller, 1980; Tedeschi, Schlenker, \& Bonoma, 1971), self-serving attributions (Weary \& Arkin, 1981), social facilitation (Bond, 1982; Sanders, 1984), psychotic symptoms (Braginsky, Braginsky, \& Ring, 1969), social anxiety and inhibition (Schlenker \& Leary, 1982b), perceived exertion (Hardy, Hall, \& Prestholdt, 1986), self-handicapping (Kolditz \& Arkin, 1982), and counseling processes (Friedlander \& Schwartz, 1985). Reviews of these literatures may be found in Baumeister (1982b, 1986), Schlenker (1980), and Tedeschi (1981).

\section{Components of Impression Management}

Our primary objective in this review was to reduce the myriad of variables that affect impression management to the smallest possible set of theoretically meaningful factors. It became clear, however, that what has been called impression management involves two discrete processes, each of which operates according to different principles and is affected by different situational and dispositional antecedents. The first process involves what we call impression motivation, the second impression construction.

People regularly monitor their impact on others and try to gauge the impressions other people form of them. Often, they do this without any attempt to create a particular impression, but simply to ensure that their public persona is intact. Under certain circumstances, however, people become motivated to control how others see them. This impression motivation process is associated with the desire to create particular impressions in others' minds, but may or may not manifest itself in overt impression-relevant actions. In some instances, people are highly motivated to manage their impressions but refrain from doing so. Thus, our review first identifies the conditions under which people become motivated to manage their public impressions.

The second component of impression management involves impression construction. Once motivated to create certain impressions, people may alter their behaviors to affect others' impressions of them. This involves not only choosing the kind of 


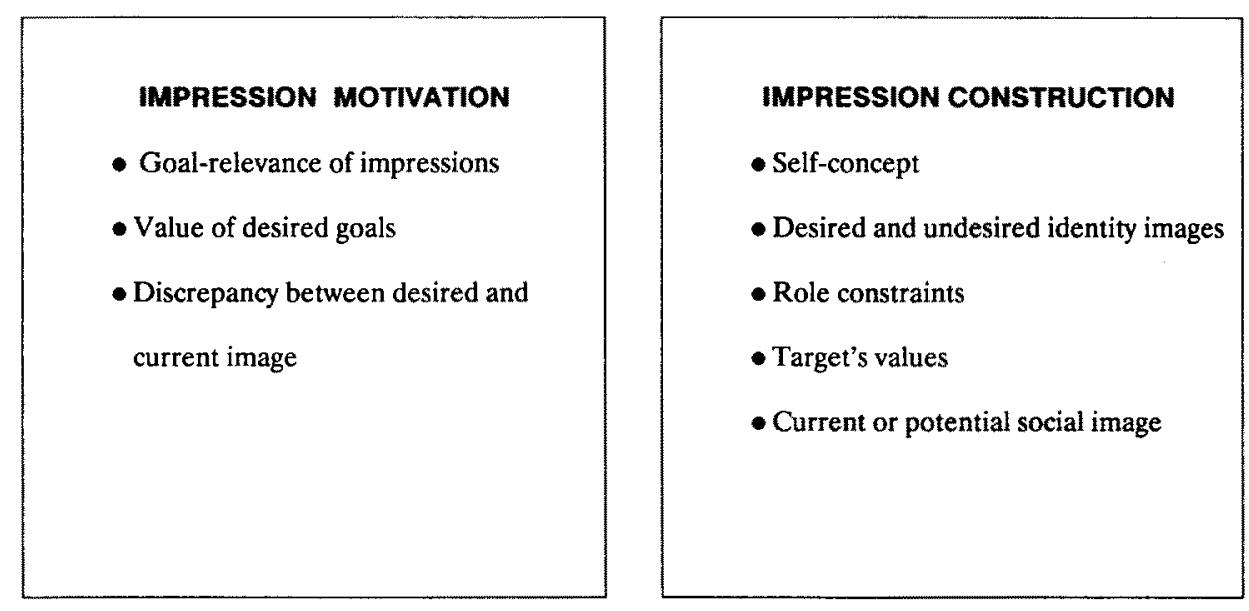

Figure 1 . The two components of impression management.

impression to create, but deciding precisely how they will go about doing so (such as deciding whether to create the desired impression via self-description, nonverbal behavior, or props, for example). Thus, our model accounts not only for why people are concerned with others' impressions of them in a particular social setting, but also for why people adopt one impression management tactic rather than another. Put another way, what has been called impression management is composed of at least two distinct subprocesses: impression motivation and impression construction.

Previous conceptual analyses of self-presentation do not distinguish clearly between these facets of impression management. For example, in his expectancy-value model, Schlenker (1980) did not separate the motive to impression-manage from the specific image one wants to create. Similarly, in their taxonomy of self-presentational strategies, E. E. Jones and Pittman (1982) defined particular strategies in terms of both the individual's interpersonal motives and the kinds of impressions created.'

In the remainder of this article, we elaborate on this two-component model of impression management and review the literature within the framework it provides. Figure I provides an overview of the model and accompanying review. According to our model, the impression motivation process is affected by three primary factors: the goal-relevance of impressions, the value of the desired outcomes, and the existing discrepancy between the individual's current image and the image he or she desires to convey. The impression construction process is affected by five factors: the person's self-concept, his or her desired (and undesired) identities, the constraints of the role in which the individual finds himself or herself, the target's values, and the person's perceptions of how he or she is regarded currently.

\section{Impression Motivation}

Although concerns about how one is perceived and evaluated by others are prevalent in everyday life, people are not always attuned to what others might be thinking about them, and do not direct all of their behaviors toward creating an impression.
Situational and dispositional factors interact to determine how attentive people are to information regarding how they are coming across to others.

\section{Levels of Impression Monitoring}

At one extreme are situations in which people are virtually oblivious of others' reactions to them. Situations that induce a state of "subjective self-awareness," for example, draw people's attention away from themselves to environmental stimuli. When in such a state, people do not hold themselves as an object of their own thoughts and thus do not process information in a self-relevant fashion (Duval \& Wicklund, 1972). In moments of ecstatic joy or in deindividuating circumstances, for example, people may fail to consider how their behavior is viewed by others (Diener, 1979; Lindskold \& Propst, 1981).

At the other extreme are situations characterized by acute public self-awareness in which people attend consciously to the aspects of themselves that others can observe, such as their appearance and behavior (Buss, 1980). When under others' intense scrutiny, for example, people find it difficult not to think about the impressions others are forming. Similarly, when the importance of making the "right" impression is salient (such as on a first date or job interview), people deliberately search for cues regarding others' impressions of them and attend selectively to information that is relevant to making the right impression.

Most of the time, however, people operate between these extremes. In general, people appear to process others' impressionrelevant reactions at a preattentive or nonconscious level. Without consciously considering how others might be perceiving them, people nonetheless scan the social environment for infor-

\footnotetext{
'Although ours is the first model to distinguish explictly between the "motivation" and "construction" components of impression management, the essential distinction has a long history in psychology. It is superficially similar, for example, to Hull's (1943) distinction between processes that energize behavior (e.g., drive) and processes that direct behavior.
} 
mation regarding how others regard them. This is a social manifestation of a more general attentional process that has received considerable attention from cognitive psychologists. Even as they devote conscious attention to one stimulus, people are able to monitor other stimuli at a preattentive level (W. Schneider \& Shiffrin, 1977). When certain stimuli are detected at a preattentive level, conscious attention may shift to those stimuli (Cherry, 1953).

Furthermore, because many patterns of self-presentation are overlearned, habitual, and unconscious (Hogan, 1982; Hogan et al., 1985; Schlenker, 1980), people sometimes engage in impression-relevant behavior with little attention to what they are doing. For example, as employees enter the boss's office, they may unconsciously tuck in their shirttails, rake their hand through their hair, and smile.

Conceiving impression monitoring as primarily a preattentive process helps to explain why people are seldom aware of attending to others' impression-relevant reactions, yet become quickly attuned to particularly good or bad appraisals from others. Furthermore, it accounts for why impression management processes do not affect all behavior, yet may be activated at any time.

Aside from general work on the topic of public self-consciousness (e.g., Buss, 1980; Fenigstein, 1987), researchers have paid scant attention to the perceptual and cognitive processes involved in attending to one's self-presentations and others' reactions to them (see, however, Baumeister, Hutton, \& Tice, in press). Most research has presented subjects with information regarding the "best" images to present or with unequivocal feedback regarding others' impressions of them. In doing so, they bypass the stages at which people begin to attend to their public images and draw inferences about how others perceive them.

\section{Primary Self-Presentational Motives}

People typically monitor the impressions others are forming without explicitly managing how they are coming across. Occasionally, however, events motivate individuals to control how others perceive them. At the most general level, the motive to engage in impression management springs from the same motivational source as all behavior, namely to maximize expected rewards and minimize expected punishments (Schlenker, 1980). This proposition is neither novel nor controversial. However, an analysis of the specific goals of self-presentational behavior sheds light on factors that motivate people to impressionmanage.

Goffman (1959) did not provide a detailed discussion of the motives that prompt self-presentational behaviors, but implied that people engage in self-presentation to control others' reactions to them. According to Goffman, self-presentation serves to define social encounters and one's role in them, definitions that then guide others' reactions. E. E. Jones and Pittman (1982) construed this motive along similar lines. They suggested that self-presentation reflects the motive to augment one's power over others. By shaping others' attributions of one's dispositions, one can influence others' behaviors in desired ways.

Schlenker (1980) proposed an expectancy-value approach to self-presentation. Every image that a person might claim has potential benefits and liabilities, outcomes that differ with respect to both their value to the individual and their perceived probability. According to Schlenker, people are motivated to claim images that have the highest potential value, although other factors (such as the sanctions that may occur if one fails in an attempt to claim an image) also determine how motivated people will be to claim particular images.

Baumeister and Tice (1986; Baumeister, 1982b) discussed two distinct motives that underlie self-presentation. On one hand, people may play to an audience in an attempt to affect their behaviors-a purely social function. Alternatively, people may engage in self-presentation as a means of constructing their public identities. Through self-presentational acts, people may attempt to make their public selves consistent with their ideal selves.

We believe that impression management may be used to increase subjective well-being in three interrelated yet distinct ways: (a) by maximizing one's reward-cost ratio in social relations, (b) by enhancing one's self-esteem, and (c) by facilitating the development of desired identities (see Rosenberg, 1979). We describe each of these motives in turn.

Social and material outcomes. Self-presentation allows people to maximize their reward-cost ratio as they deal with others (Schlenker, 1980). Conveying the right impression increases the likelihood that one will obtain desired outcomes and avoid undesired outcomes. Some such outcomes are interpersonal in nature, such as approval, friendship, assistance, power, and so on Other such outcomes are material. For example, being viewed as competent may result in a raise in salary or in better working conditions.

The use of impression management in the acquisition of desired social and material outcomes has been widely studied and well documented (Schlenker, 1980; Tedeschi, 1981). However, the fact that people often are concerned with how others perceive them even when no immediate or future outcomes depend on the impressions they make suggests that other factors may motivate impression management.

Self-esteem maintenance. The idea that people are motivated to maintain and enhance their self-esteem has achieved the status of an axiom within personality and social psychology (Adler, 1930; Allport, 1955; S. C. Jones, 1973; Rogers, 1959; Rosenberg, 1979). People may engage in impression management to regulate their self-esteem in two ways. First, others' reactions to the individual may raise or deflate self-esteem. Compliments, praise, and indications of liking serve to enhance self-esteem, whereas criticism and rejection deflate it. As a result, people often try to make impressions that will elicit esteem-enhancing reactions, particularly when they expect feedback from others (D. J. Schneider, 1969).

Second, self-esteem is affected by people's self-evaluations of their performances and others' imagined reactions to them. People may perceive they have made a good or bad impression and experience resulting changes in self-esteem in the absence of explicit or implicit feedback from others (Darley \& Goethals, 1980; Filter \& Gross, 1975; Reis \& Gruzen, 1976).

Development of identity. People also engage in self-presentation as a means of creating their identities (Baumeister, 1982b; Gollwitzer, 1986; Wicklund \& Gollwitzer, 1982). Gollwitzer 
(1986) proposed that acquiring a particular identity "requires the execution of identity-related activities" (p. 145). Because identity is ultimately derived from society (Cooley, 1902; Mead, 1934), people sometimes "seif-symbolize," that is, engage in public behaviors that indicate the possession of identity-relevant characteristics. For example, a new assistant professor can solidify his or her identity as an academician by behaving like a faculty member "should" behave.

Proponents of symbolic self-completion theory have drawn a distinction between self-symbolizing and self-presentation, however. Gollwitzer (1986) maintained that self-symbolizing activities are not responsive to many of the variables that affect self-presentation (such as target characteristics) and, thus, do not involve self-presentation. Because we construe self-presentation more broadly, we believe that self-symbolizing (as described by Wicklund \& Gollwitzer, 1982) does involve self-presentational processes. In some instances of self-symbolizing, audience reactions may be relatively immaterial; as is seen later, variables other than the target's characteristics and values affect self-presentation. In other cases, however, development of one's identity occurs through impression-relevant behaviors that are responsive to interpersonal factors.

Although these can be regarded as three distinct motives, the specific factors that elicit them overlap substantially. For example, self-presentational behaviors that obtain rewards from others are often those that raise self-esteem and establish desired identities as well. There are exceptions, however. For example, the impressions that result in valued outcomes sometimes involve presenting an unfavorable view of oneself, thereby lowering self-esteem (as when a woman "plays dumb" to impress her chauvinistic date; Gove, Hughes, \& Geerken, 1980). However, relatively little research has examined how people respond to impressional dilemmas in which these motives conflict (Leary \& Lamphere, 1988).

\section{Antecedents of Impression Motivation}

The degree to which people are motivated to control how others perceive them is affected by a variety of situational and dispositional variables. In our theoretical scheme, these are subsumed by three central factors that determine impression motivation: the goal-relevance of the impressions, the value of the desired outcomes, and the discrepancy between one's desired and current social image. We discuss each of these in turn.

Goal-relevance of impressions. People are more motivated to impression-manage when the impressions they make are relevant to the fulfillment of one or more of the goals we have described (social and material outcomes, self-esteem maintenance, identity development). In cases in which one's impressions have few, if any, implications for one's outcomes, self-esteem, or identity, the motive to impression-manage will be low.

What factors determine how relevant one's impressions are to the fulfillment of these goals? Of central importance is the publicity of one's behavior. Publicity is a function of both the probability that one's behavior will be observed by others and the number of others who might see or learn about it. Overall, the more public one's behavior, the more likely one is to be concerned with how it appears to others, and the more motivated one will be to impression-manage (Arkin, Appelman, \& Berger, 1980; Baumgardner \& Levy, 1987; Bradley, 1978; House, 1980; Reis \& Gruzen, 1976). Publicity affects impression motivation because public behaviors are more likely to be relevant to the accomplishment of one's goals than are private behaviors. Indeed, all three of the motives we have described are more likely to be fulfilled when one's behaviors are public rather than private.

Even so, private behaviors can be affected by self-presentational motives. For example, people may privately prepare to perform impression-relevant behaviors in public. Furthermore, public behaviors that are maintained in social situations by selfpresentational pressures may become so habitual that they carry over into private settings.

Another factor affecting the goal-relevance of one's impressions involves the individual's dependency on the target. When a person is dependent on others for valued outcomes, the impressions he or she makes on them are more important, and the individual will be more motivated to engage in impression management. As a result, people are more likely to ingratiate themselves with their bosses and teachers than with their friends (Bohra \& Pandey, 1984; Hendricks \& Brickman, 1974) and more likely to ingratiate these authorities when they have greater power to dispense valued outcomes (E. E. Jones et al., 1965; Kowalski \& Leary, in press; Stires \& Jones, 1969).

Impressions also become more relevant to one's goals the more contact an individual expects to have with a target. Studies show that people who expect future interactions with another person are more likely to try to control how the other perceives them (Gergen \& Wishnov, 1965; D. J. Schneider, 1969).

Of course, some people are more motivated to impressionmanage than others. For example, people high in Machiavellianism are particularly likely to engage in strategic self-presentation to influence others (Christie \& Geis, 1970; Fontana, 1971; see, however, E. E. Jones et al., 1962). In part, this is because those high in Machiavellianism are more likely to see the impressions they create as relevant to the accomplishment of their goals (Christie \& Geis, 1970).

Value of desired goals. Most theories of motivation assert that motivation increases as a function of the value or importance of desired goals (Beck, 1983). Following this, impression motivation should increase with the value of the goals an individual hopes to attain for which his or her public impressions are relevant. Thus, a job applicant will be more motivated to manage his or her impressions before an interviewer if the job is highly desirable than if it is not, for example.

Because the value of outcomes also increases as their availability goes down, impression motivation is higher when desired resources are scarce. Pandey and Rastagi (1979) showed that ingratiation to a job interviewer increased as competition for the job became more intense. Extending these findings to a societal level, Pandey (1986) suggested that impression management may be more common in societies with limited economic and political opportunities. His studies of ingratiation in India are among the few to examine the effects of societal factors on self-presentation and provide insights for future cross-cultural research on impression management.

Other variables that determine the value or importance of creating an impression involve characteristics of the target. By 
virtue of their personal or social attributes, some targets prompt others to monitor and control their impressions more than do others. All other things being equal, people are more motivated to manage their impressions for people who are powerful, of high status, attractive, or likable than for those who are less so (Schlenker, 1980).

This is because targets with these characteristics are, overall, more likely to satisfy the three motives we described earlier. First, targets who are of high power or status are often in a position to confer valued outcomes. Employers, teachers, supervisors, and other authorities are likely to bestow positive outcomes on those who suitably impress them and negative outcomes on those who do not. Thus, impression motivation is higher when one interacts with those who are powerful or of high status (Gergen \& Taylor, 1969; E. E. Jones et al., 1963). Not surprisingly, subordinates ingratiate themselves with their supervisors more than supervisors ingratiate themselves with their subordinates (Pandey, 1981, 1986). This is not to say that those of higher status do not manage their impressions for their subordinates (they have their own motives for doing so), but generally the motivation to impress one's subordinates is lower.

Target characteristics may also affect self-esteem. People value the evaluations and reactions of powerful, attractive, socially desirable individuals more than they value those of less desirable persons; their regard is more affirming and their disinterest and rejection more disturbing (Schlenker, 1980). Studies show that manipulations designed to affect impression management have stronger effects when the target is physically attractive or otherwise socially desirable (Forsyth, Riess, \& Schlenker, 1977; Mori, Chaiken, \& Pliner, 1987; Shaw \& Wagner, 1975; Zanna \& Pack, 1975).

Third, targets with certain attributes are more relevant to the development of particular identities. For a psychology graduate student, for example, making a good impression on a psychologist facilitates development of one's identity as a psychologist better than making a similar impression on one's parents or another professional.

Individual differences in the degree to which people value various outcomes should also be associated with impression motivation. Notably, people who are high in need for approval (Crowne \& Marlowe, 1964) more highly value others' acceptance and approval than people who are low on this trait. As a result, high need for approval is associated with generally high impression motivation (Dies, 1970; S. C. Jones \& Tager, 1972; Leary, 1983; Millham \& Kellogg, 1980; D. J. Schneider \& Turkat, 1975).

Discrepancy between desired and current image. The third factor that motivates impression management involves the degree of discrepancy between the image one would like others to hold of oneself and the image one believes others already hold. People have a latitude of images that they regard as acceptable to project. When they believe that the impressions others have of them fall outside this latitude, they become motivated to actively manage their impressions. However, if they perceive, correctly or incorrectly, that they are conveying an image that falls within this latitude, impression motivation should be lower, although not necessarily zero.

A common example of this involves situations in which people think others hold less positive impressions of them than they desire, as in the case of a public failure or an embarrassing incident. In several studies, subjects have been led to think that they failed on an important task (Baumeister \& Jones, 1978; Baumgardner, Lake, \& Arkin, 1985; Cialdini \& Richardson, 1980; Frey, 1978; Leary \& Schlenker, 1980; Schlenker, 1975; D. J. Schneider, 1969) or have been embarrassed in front of others (Apsler, 1975; Brown, 1968, 1970; Brown \& Garland, 1971; Modigliani, 1971; see R. S. Miller, 1986). Both failure and embarrassment increase impression motivation. On one hand, people who have failed or been embarrassed will seek to repair their damaged images in others' eyes. They may do this, for example, by stressing their positive attributes (Baumeister \& Jones, 1978; D. J. Schneider, 1969), doing favors for others (Apsler, 1975), associating themselves with other successful people (Cialdini \& Richardson, 1980), or making self-serving attributions for their failure (Baumgardner et al., 1985; Frey, 1978; Weary \& Arkin, 1981). People facing a possible threat to their social image may even engage in such behaviors preemptively-before actually failing-as a precaution (Greenberg, Pyszczynski, \& Paisley, 1984; Leary, Barnes, \& Griebel, 1986).

Simultaneously, embarrassment and failure may threaten self-esteem and cast doubts on aspects of one's private identity. One way to repair this damage is to display positive "identity cues" (Gollwitzer, 1986; Modigliani, 1971; Swann, 1987). This explains two puzzling effects of failure on impression management: Public failures before one target often lead to more positive self-presentations to others who are not aware of the failure (Apsler, 1975), and even failures that are known only to the individual himself or herself can affect impression-relevant behavior (Modigliani, 1971). In both instances, people may use impression management to salvage their self-esteem and bolster desired private identities that have been called into question by the predicament.

Summary. Impression motivation is a function of three interrelated factors: the goal-relevance of impressions, the value of desired outcomes, and the perceived discrepancy between one's desired and current social image. Each of these factors increases the degree to which people attempt to control others' impressions because each affects the attainment of desired outcomes, the maintenance of self-esteem, and the development of desired identities.

\section{Impression Construction}

Given that a person is motivated to create an impression on others, the issue becomes one of determining precisely the kind of impression one wants to make and choosing how one will go about making that impression.

Many writers have portrayed impression management rather narrowly: as involving primarily attempts to create impressions of one's personal characteristics. Furthermore, some have treated impression management as being more or less equivalent to self-description. Our view of impression management is much broader, including all behavioral attempts to create impressions in others' minds. People attempt to create impressions not only of their personal attributes, but also of their attitudes, moods, roles, status, physical states, interests, beliefs, and so on. People also use means other than self-description to create desired impressions. Consistent with E. E. Jones and Pitt- 
man (1982), we include in our purview not only verbal communications about oneself, but also stylistic and nonverbal features of behavior, such as nonverbal behavior (Henley, 1977; Riess, 1982), public attributions (Leary \& Forsyth, 1987; Weary \& Arkin, 1981), association with other people or groups (Cialdini et al., 1976), physical appearance (L. C. Miller \& Cox, 1982), conspicuous use of material possessions (Schlenker, 1980), and even the food one eats (Mori et al., 1987).

\section{Determinants of Impression Content}

Experimental investigations have identified a number of variables that influence the manner in which people manage their impressions. In our model, these are subsumed by five primary factors. Two of these involve intrapersonal variables (self-concept and desired identity), and three involve interpersonal determinants (role constraints, target values, and current or potential social image).

Self-concept. Some writers have criticized impression management models because they argue that such models emphasize "pretense" in which people "portray a character different from themselves" (Buss \& Briggs, 1984, p. 1322). On the contrary, nothing in the impression management perspective implies that the impressions people convey are necessarily false (although, of course, they sometimes are). Indeed, the images people try to project are often consistent with how they see themselves (Gergen, 1968; E. E. Jones \& Pittman, 1982; Schlenker, 1980).

The self-concept is a primary determinant of the impressions people try to project. Three processes operate to make this so. First, most people value certain aspects of themselves that they proudly display to others at appropriate times. Impression management often involves an attempt to put the best parts of oneself into public view. In fact, people may impression-manage to ensure that others accurately perceive them. Although it may seem paradoxical, conscious effort sometimes is required to be sure others hold a veridical view of oneself (Goffman, 1959). Thus, although people's self-presentations may be tactical in the sense that they select specific aspects of self to portray in a particular encounter and consciously control how those images are expressed, claimed images often mirror people's self-concepts.

Second, people's self-beliefs operate to constrain self-presentations by providing information regarding the probability that they can successfully foster particular impressions. People hesitate to claim images that are inconsistent with how they see themselves because of the possibility that they cannot pull it off (Schlenker, 1980). Norms dictate that people are who and what they appear to be (Gergen, 1968; Goffman, 1959). As Goffman (1959) noted, "an individual who implicitly or explicitly signifies that he has certain social characteristics ought in fact to be what he claims he is" (p. 13). The self-concept provides a guide to the reasonableness of trying to create certain impressions. When they are unlikely to be found out, people may try to present themselves more positively than is warranted (Baumeister, 1982a; Baumeister \& Jones, 1978; Schlenker, 1975).

Third, most people have internalized an ethic against lying. This belief in the immorality of deceit (and the resulting guilt when it is compromised) deters most people from making claims about themselves that are blatantly inconsistent with their self-concepts. Of course, people allow themselves some leeway in how discrepant their behaviors may be from their selfconcepts before labeling them as deceitful. In addition, most people allow for exceptions in which self-presentational deceit is permissable.

The processes involved in self-presentational dissimulation have not been adequately investigated, and many questions call for future research attention. For example, what conditions provoke people to act against their values regarding deceit and to construct public images that are inconsistent with their selfconcepts? How far do people go in fostering distorted impressions of themselves before they label such behaviors as deceitful? What are people's preferred strategies for creating impressions that are not accurate? What are the subjective consequences of dissimulation, and what are the implications for subsequent social behavior?

Buss and Briggs (1984) discussed some of the conditions under which pretense is most likely to occur. They proposed, for example, that pretense is more likely for individuals employed in highly visible occupations, such as politicians, teachers, clergy, and salespeople. Furthermore, they suggested that pretense occurs more often in superficial relationships; as a relationship deepens, it becomes increasingly difficult (and, perhaps, decreasingly necessary) to maintain the deception.

Inasmuch as pretense is essentially self-relevant lying, the literature regarding deceit provides additional insights into dissimulation. In his excellent analysis of lying and its consequences, Bok (1978) suggested that deceivers may come to regard both themselves and the targets of their lies less positively and find it easier to deceive in the future. DePaulo, Stone, and Lassiter (1985) traced the developmental sequence of deceptive abilities and discussed their relevance for understanding impression management. The antecedents and consequences of deceptive self-presentation are ripe topics for empirical research.

Interestingly, people differ in how congruent their self-presentations are with their self-perceptions. People who are high in public self-consciousness, for example, show less congruency between their private and public selves than do people low in public self-consciousness (Tunnell, 1984). Thus, although selfpresentations are often consistent with the private self (as classic consistency theories predict; Festinger, 1957), they are not necessarily so (S. C. Jones, 1973; Schlenker, 1975).

Desired and undesired identity images. Self-presentations are affected not only by how people think they are but by how they would like to be and not be. Schlenker $(1985$, p. 74$)$ sug. gested the term desirable identity image to refer to what a person "would like to be and thinks he or she really can be, at least at his or her best" (see also Markus \& Nurius, 1986). People tend to convey impressions that are biased in the direction of their desired identities. In part, this involves the self-symbolizing process discussed by symbolic self-completion theory (Gollwitzer, 1986). People can develop desired identities by publicly claiming attributes that are consistent with those identities. In addition, behaving consistently with one's desired identities enhances self-esteem. Either way, the images people project sometimes lean toward their desired identities while remaining within the bounds of reality.

People also manage their impressions so as not to be consis- 
tent with undesired identity images - those things that the individual does not want to be (cf. Ogilvie, 1987; Schlenker, 1985). Thus, a man who abhors bigots may bend over backwards to be sure he does not give the slightest hint of appearing bigoted. In a study of the self-presentations of naval cadets, Gergen and Taylor (1969) found that high-status subjects did not conform to low-status subjects because they did not want to see themselves as conformists.

All other things being equal, people seem to strike a balance between presenting themselves in a perfectly candid fashion and claiming images that only portray them at their best (Schlenker, 1985). As a result, public impressions reflect an interplay between the self-concept and desired-undesired identity images.

Role constraints. Social roles carry expectations regarding how individuals who occupy those roles are to behave (Sarbin \& Allen, 1968). In addition to specific behavioral prescriptions, most roles require that people who occupy them appear to be a particular kind of person or possess certain personal characteristics. An obvious example involves members of the clergy, who usually go out of their way to avoid situations that might cast doubt on their public image as individuals of impeccable morals. Similarly, the effectiveness of people in positions of authority depends, to a degree, on their ability to maintain public images of being competent and effective leaders (Calder, 1977; Korda, 1975; Leary, Robertson, Barnes, \& Miller, 1986). The failure to convey impressions consistent with one's role not only diminishes one's effectiveness in that role, but in many cases can lead the individual to lose the right to enact that role (Goffman, 1959). Out-of-role behaviors, impressions of incompetency or impropriety, and frequent norm violations have led to the downfall of many politicians, religious leaders, and corporate executives, for example.

As a result, people try to ensure that their public image is consistent with (or at least is not inconsistent with) the role demands of a particular situation. E. E. Jones et al. (1963) found, for example, that low- and high-status Reserve Officers' Training Corps cadets differentially managed their impressions so as to create a positive impression within the constraints of their positions. Leary, Robertson, et al. (1986) found that leaders of small groups attempted to foster different impressions of themselves depending on the role requirements of the immediate situation (see also Gergen \& Taylor, 1969). Piliavin (1976) proposed that many behavioral differences between men and women reflect self-presentational responses to role expectations (see also Deaux \& Major, 1987).

Impression management in role-governed situations is often based on a prototype-matching process. People try to make their social images conform as closely as possible to prototypic characteristics of the role they are playing (leader, minister, police officer, teacher, or whatever; Leary, 1989).

Goffman (1959) provided an insightful analysis of the rolegoverned nature of self-presentation. He observed, for example, that although roles require people to maintain certain "faces" before particular targets, these public performances are knowingly contradicted as a matter of course when the individual retreats to a "back region." When the target is no longer present, the individual "can relax; he can drop his front, forgo speaking his lines, and step out of character" (p. 112). Goffman noted that when impression-relevant norms are suspended in back re- gions, behavior often takes on a "regressive" character, involving behaviors such as excessive informality, substandard speech, kidding, and open sexual remarks. ${ }^{2}$

In other contexts, norms mandate that people reciprocate the intimacy and content of others' disclosures (Cozby, 1973). As a result, they tend to match their self-presentations to those of other interactants (Gergen \& Wishnov, 1965; D. J. Schneider \& Eustis, 1972). For example, people respond to others' modest self-disclosures with modest self-presentations of their own (Gergen \& Wishnov, 1965). To fail to do so would violate interaction norms and result in negative sanctions.

Target values. Considerable research has shown that people tailor their public images to the perceived values and preferences of significant others (Carnevale, Pruitt, \& Britton, 1979; Forsyth et al., 1977; Gaes \& Tedeschi, 1978; Gergen, 1965; R. G. Jones \& Jones, 1964; Mori et al., 1987; Reis \& Gruzen, 1976; von Baeyer, Sherk, \& Zanna, 1981; Zanna \& Pack, 1975). They may even present themselves negatively if they think powerful others value negative attributes (Jellison \& Gentry, 1978) or would be threatened by a positive self-presentation, as in the case of playing dumb (Dean, Braito, Powers, \& Britton, 1975; Gove et al., 1980).

That others' preferences affect self-presentation does not imply, however, that the impressions created are necessarily deceptive. Even when people match others' likes, they often do so by selectively conveying accurate views of themselves. They select from a myriad of possible self-images those that are most likely to meet with approval or other desired reactions. Impression management in such contexts is tactical, but not necessarily deceptive.

Of course, people sometimes do try to create impressions that are consistent with the target's values yet inconsistent with how they see themselves. Under such circumstances, they are particularly interested in obtaining information about the target (Elliott, 1979). One study suggested that when people try to make impressions that are inconsistent with how they see themselves in order to impress someone, they prefer to do so through exclusionary self-presentational tactics; they try to omit information about themselves that does not fit the target's values, while refraining from actually lying (Leary \& Lamphere, 1988).

We should note that people sometimes present themselves in ways that are inconsistent with the target's values. They may do so, for example, when they want to alienate or avoid another person (H. M. Rosenfeld, 1966) or maintain their sense of autonomy (Gergen \& Taylor, 1969).

Current or potential social image. Finally, the impressions people try to create are affected both by how they think they are currently regarded by others and by how they think others may perceive them in the future (on the basis of future revelations about them, for example).

In some instances, information that others have or are likely to get about the individual constrains the individual's subsequent attempts at impression management. These constraints

\footnotetext{
${ }^{2}$ Goffman went on to raise the interesting question of whether "a backstage gives individuals an opportunity to regress or whether regression, in the clinical sense, is backstage conduct invoked on inappropriate occasions for motives that are not socially approved" (1959, p. 128).
} 
may be either restraining (preventing certain impression management strategies) or compelling (requiring certain strategies).

First, people are reluctant to present themselves in ways that are inconsistent with the information others have about them, presumably because they have a low probability of creating an alternative impression (Schlenker, 1980). Schlenker (1975) gave subjects bogus feedback indicating that they were either low or high in social sensitivity. Some subjects thought others were aware of this information, whereas others thought the information was known only to them. Subjects presented themselves consistently with the information when they thought it was public, thereby demonstrating the constraining effects of others' knowledge. When their scores were private, however, their selfpresentations were uniformly positive regardless of how well they had scored on the test.

In a study of how subjects deal with the constraining effects of others' knowledge, Baumeister and Jones (1978) showed that subjects whose failures were public compensated for their negative images by presenting themselves more positively on dimensions that were unrelated to the failure. Baumeister (1982a) later showed that this effect occurs primarily among people who are high in self-esteem.

One's current image can also compel certain self-presentations. When one's accomplishments are already public knowledge, for example, there are pressures to downplay them in a show of modesty (Ackerman \& Schlenker, 1975). People are liked better when they slightly underplay their accomplishments (Schlenker \& Leary, 1982a).

Public failures and embarrassing events compel people to engage in impressional strategies designed to counter or repair the damaged image (Goffman, 1955). Believing that one's social image is other than what one would like prompts face-saving strategies such as excuse-making (Snyder, Stucky, \& Higgins, 1983), apologies (Schlenker \& Darby, 1981), self-serving attributions (Weary \& Arkin, 1981), doing favors (Apsler, 1975), denigrating others (Cialdini \& Richardson, 1980), role-distancing (Archibald \& Cohen, 1971), and compensatory impression management (Baumeister, 1982a; Baumeister \& Jones, 1978; Hardy et al., 1986; Leary \& Schlenker, 1980). Even eating can serve an impression-repair function; in one study, women who thought a male lunch partner viewed them as masculine ate less than women who thought they were perceived as feminine (Mori et al., 1987). By eating lightly, women tried to be seen as more feminine.

In an extension of this principle to another area of social psychological inquiry, the impression management approach suggests that attitude change that occurs after performance of a counterattitudinal behavior (e.g., Festinger \& Carlsmith, 1959) may represent subjects' attempts to repair damaged social images. Having performed a socially undesirable act before others, subjects in induced-compliance studies may endorse attitudes consistent with their behavior in order not to be perceived as inconsistent or immoral (Tedeschi et al., 1971). In essence, concerns about current social image prompt a strategic use of attitude expressions. The findings of several studies are consistent with this interpretation (e.g., Gaes, Kalle, \& Tedeschi, 1978; P. Rosenfeld, Melburg, \& Tedeschi, 1981; Schlenker et al., 1980).

Being perceived in certain ways also entitles people to claim certain images. Hollander (1958), for example, proposed that by conforming to group norms, people accumulate "idiosyncrasy credits" that allow them to deviate from norms in the future. In the same way, occasional displays of irresponsibility are more permissable from those who are normally conscientious than from those who are not.

The content of people's impression management is also affected by how they think they may be viewed in the future. The possibility that others may learn certain information about them in the future affects impression management. For example, the possibility of future failure prompts preemptive attempts to diffuse the potential failure in others' eyes (Leary, Barnes, \& Griebel, 1986; Quattrone \& Jones, 1978).

Summary. In brief, five primary factors determine the specific nature of the public images that individuals try to construct of themselves (see Figure 1). Research is needed regarding how these factors combine to affect self-presentational choices, on variables that determine which factor takes precedence in instances in which more than one is salient, and how conflicts between competing pressures are resolved.

Earlier, we noted that impression construction involves both the process of determining the kind of impression one will try to make and choosing how one will go about making that impression. Our review in this section has focused only on the first of these processes because no research has explored how people select the behavioral modes they use to manage their impressions. Sometimes, people make direct claims regarding their attributes (e.g., "I guess I'm not very sentimental") or make other verbal statements that portray them in a particular way (e.g., "I didn't like On Golden Pond; it was too sentimental"). In other instances, they use nonverbal expressions to convey the desired image (for example, by remaining obviously unemotional during a sentimental moment). Although it is a difficult topic to address empirically, work is needed on factors that determine the behavioral modes people use to manage their impressions. ${ }^{3}$

\section{Theoretical Overview and Issues}

From our perspective, all situational and dispositional factors that affect impression-relevant behavior motivate people to manage their impressions or determine the particular manner in which they construct their public images. Furthermore, we have identified three central factors that determine impression motivation and five central factors that determine the mode of impression construction. To conclude, we address three issues regarding the study of impression management in general and our two-component model in particular.

\section{Motivation-Construction Distinction}

Our approach draws a central distinction between the processes that motivate impression-relevant behavior and those that determine the content of those behaviors. Unfortunately, in reviewing the research literature, we often found it difficult to determine whether experimental manipulations in a particular

\footnotetext{
${ }^{3}$ As a starting point, researchers might consider factors that determine the directness of a self-presentational strategy. Some modes of selfpresentation involve direct and explicit claims regarding the individual's characteristics, whereas others are more subtle.
} 
study had affected impression motivation processes, impression construction processes, or both.

In part, the ambiguity is due to the fact that these two processes are sometimes confounded in real-world encounters. Some variables affect only one process or the other. For instance, the value of desired goals affects impression motivation but has little effect on the content of the impressions one attempts to create.

However, as we have seen, other variables appear to affect both impression motivation and impression construction processes. For example, an interaction with a job interviewer may have two effects. Assuming that one wants the job, it increases the applicant's motivation to engage in impression management. In addition, the situation provides the parameters within which the applicant's impression-relevant behaviors occur. Certain impressions become salient (such as those involving jobrelated competence), and certain constraints on self-presentation are imposed (particularly if the interviewer possesses one's academic records and letters from previous employers).

To be precise, however, different facets of the interview affect each of these processes. The interviewer's power to mediate valued outcomes increases impression motivation, whereas his or her possession of information about the applicant imposes constraints that affect impression construction. Unfortunately, self-presentational research usually has tended to focus on rather global social variables (such as target status or desirability) that have several effects on impression management. We urge researchers to maintain the distinction we offer here in future research and to use designs and measures that allow one to examine the independent effects of various factors on these basic impression-relevant processes.

\section{Impression Assessment}

For ease of description, we have portrayed impression management as a linear process in which people become motivated to impression-manage, then go about doing so. However, the process is actually dynamic and recursive. As in any goal-directed behavior, impression management is accompanied by assessments of its effectiveness in achieving one's goals (Carver, 1979; G. A. Miller, Galanter, \& Pribram, 1960; Schlenker, 1985). These assessments then affect not only subsequent behavior, but feedback on the factors that affect impression motivation and construction.

When people believe they have achieved their self-presentational goals in an encounter, they usually halt active attempts to create particular impressions. Even so, they may attempt to maintain the created impression by avoiding behaviors inconsistent with it.

If people do not think they have yet created the desired impression, one of three outcomes may result. If they perceive that there is a reasonable probability of making the desired impression with continued effort, they may continue to behave in ways that they think will convey the impression they want. If they do not think they will eventually be successful at making the desired impression, they may switch to an alternative impression. In some instances, one's goals may be achieved through more than one public image. For example, if a person tries to impress another with his or her wit and fails, he or she may opt to create an impression of sophistication (or sincerity or whatever). Similarly, if a person has failed publicly and gives up attempting to appear competent, he or she may try to be seen as friendly instead (Baumeister \& Jones, 1978; Leary \& Schlenker, 1980).

If, however, people do not think they will make desired impressions no matter what they do, they may adopt a "protective" self-presentational strategy (Arkin, 1981). Protective strategies are used to ward off deterioration of one's public image, but forgo further attempts to actively foster particular desired impressions. In addition, people who are motivated to make certain impressions, but who doubt they will do so successfully, usually experience social anxiety and behave in an inhibited, shy manner (Leary, 1983; Schlenker \& Leary, 1982b). In part, their reticence may reflect a protective self-presentational strategy that further minimizes the likelihood that they will be evaluated unfavorably (Arkin, 1981; Leary, 1983; Leary, Knight, \& Johnson, 1987).

Judgments of one's self-presentational effectiveness may also result in changes in the factors that originally prompted the impression-relevant behavior. For example, reassessment of one's impact may show that one's current image is either more or less discrepant with one's desired image than before; or assessments of one's self-presentational effectiveness may affect one's "working self-concept" or phenomenal self, thereby affecting self-presentation (E. E. Jones, Berglas, Rhodewalt, \& Skelton, 1981; Rhodewalt, 1986). Unfortunately, little research has investigated how people judge the effectiveness of their public impressions or the effects these assessments have on their subsequent behavior (see, however, DePaulo, Kenny, Hoover, Webb, \& Oliver, 1987; Leary, 1983).

\section{Public and Private Selves}

Much recent work has attempted to integrate the public aspects of the self (including self-presentation) with the private aspects (Baumeister, 1986; Buss, 1980; Greenwald \& Breckler, 1985; Schlenker, 1985; Tetlock \& Manstead, 1985). Although some have argued that the distinction between public and private aspects of the self has little if any merit (Tetlock \& Manstead, 1985; Wicklund \& Gollwitzer, 1987), others defend the distinction (e.g., Buss, 1980; Fenigstein, 1987; Greenwald, 1982), and some empirical evidence supports it (Leary et al., 1986; Leary, Barnes, Griebel, Mason, \& McCormack, 1987). ${ }^{4}$

Our model explicitly highlights points of connection between the private self and impression management. Three such points are paramount. First, one's standards for self-evaluation are implicated both in motivating impression-relevant behavior and in determining the form that impression management takes. Second, one's private self-concept has an impact on one's selfpresentational choices. Third, one's desired and undesired

\footnotetext{
${ }^{4}$ The debate regarding the viability of the distinction between public and private self-awareness has been particularly lively (e.g., Buss, 1980; Fenigstein, 1987; Wicklund \& Gollwitzer, 1987). We believe this particular controversy may be settled, in part, by simply moving a hyphen. In our view, the appropriate terms should be public-self awareness and private-self awareness, indicating that the difference between these phenomena is in the object of attention (the public self or private self) rather than in the state of self-awareness per se.
} 
selves channel the impressions one attempts to convey. Furthermore, although our review has focused on antecedents of impression management, it is clear that self-presentation has consequences for the private self as well (E. E. Jones et al., 1981). To discuss more fully the links between the private and public aspects of the self would take us far beyond our purpose in this article. Suffice it to say that the two-factor model outlined here identifies the linkages between private and public self, as well as ways in which private and public self-processes may diverge.

In conclusion, we believe that the model that has provided the basis for this review provides a comprehensive account of the processes involved in impression-relevant behavior. Furthermore, it addresses many of the controversial issues in the area and provides a framework for future research regarding impression management.

\section{References}

Ackerman, B., \& Schlenker, B. R. (1975). Self-presentation: Attributes of the actor and audience. Paper presented at the 83rd annual meeting of the American Psychological Association, Chicago.

Adler, A. (1930). Individual psychology. In C. Murchinson (Ed.), Psychologies of 1930 (pp. 395-405). Worcester, MA: Clark University Press.

Allport, G. (1955). Becoming. New Haven, CT: Yale University Press.

Apsler, R. (1975). Effects of embarrassment on behavior toward others. Journal of Personality and Social Psychology, 32, 145-153.

Archibald, W. R., \& Cohen, R. L. (1971). Self-presentation, embarrassment, and facework as a function of self-evaluation, conditions of selfpresentation, and feedback from others. Journal of Personality and Social Psychology, 29, 287-297.

Arkin, R. M. (1981). Self-presentational styles. In J. T. Tedeschi (Ed.), Impression management theory and social psychological research (pp. 311-333). New York: Academic Press.

Arkin, R. M., Appelman, A. J., \& Berger, J. M. (1980). Social anxiety, self-presentation, and the self-serving bias in causal attribution. Journal of Personality and Social Psychology, 38, 23-35.

Arkin, R. M., \& Baumgardner, A. H. (1986). Self-presentation and selfevaluation: Processes of self-control and social control. In R. F. Baumeister (Ed.), Public self and private self (pp. 75-97). New York: Springer-Verlag.

Baumeister, R. F. (1982a). Self-esteem, self-presentation, and future interaction: A dilemma of reputation. Journal of Personality, 50, 2945.

Baumeister, R. F. (1982b). A self-presentational view of social phenomena. Psychological Bulletin, 91, 3-26.

Baumeister, R. F. (Ed.). (1986). Public self and private self. New York: Springer-Verlag.

Baumeister, R. F., Hutton, D. G., \& Tice, D. M. (in press). Cognitive processes during deliberate self-presentation: How self-presenters alter and misinterpret the behavior of their interaction partners. Journal of Experimental Social Psychology.

Baumeister, R. F., \& Jones, E. E. (1978). When self-presentation is constrained by the target's knowledge: Consistency and compensation. Journal of Personality and Social Psychology, 36, 608-618.

Baumeister, R. F., \& Tice, D. M. (1986). Four selves, two motives, and a substitute process self-regulation model. In R. F. Baumeister (Ed.), Public self and private self (pp. 63-74). New York: Springer-Verlag.

Baumgardner, A. H., Lake, E., \& Arkin, R. M. (1985). Claiming mood as a self-handicap: The influence of spoiled and unspoiled public identity. Personality and Social Psychology Bulletin, 11, 349-357.

Baumgardner, A. H., \& Levy, P. E. (1987). Interpersonal reactions to social approval and disapproval: The strategic regulation of affect. Manuscript submitted for publication, Michigan State University.
Beck, R. C. (1983). Motivation: Theories and principles (2nd ed.). Englewood Cliffs, NJ: Prentice-Hall.

Bohra, K. A., \& Pandey, J. (1984). Ingratiation toward strangers, friends, and bosses. Journal of Social Psychology, 22, 217-222.

Bok, S. (1978). Lying: Moral choice in public and private life. New York: Pantheon.

Bond, C. F. (1982). Social facilitation: A self-presentational view. Journal of Personality and Social Psychology, 42, 1042-1050.

Bradley, G. W. (1978). Self-serving biases in the attribution process: A reexamination of the fact or fiction question. Journal of Personality and Social Psychology, 36, 56-71.

Braginsky, B. M., Braginsky, D. D., \& Ring, K. (1969). Methods of madness: The mental hospital as a last resort. New York: Holt, Rinehart \& Winston.

Brown, B. R. (1968). The effects of need to maintain face on interpersonal bargaining. Journal of Experimental Social Psychology, 4, 107122.

Brown, B. R. (1970). Face-saving following experimentally-induced embarrassment. Journal of Experimental Social Psychology, 6, 255-271.

Brown, B. R., \& Garland, H. (1971). The effects of incompetency, audience acquaintanceship, and anticipated evaluative feedback on facesaving behavior. Journal of Experimental Social Psychology, 7, 490502.

Buss, A. H. (1980). Self-consciousness and social anxiety. San Francisco: Freeman.

Buss, A. H., \& Briggs, S. (1984). Drama and the self in social interaction. Journal of Personality and Social Psychology, 47, 1310-1324.

Calder, B. J. (1977). An attribution theory of leadership. In J. Salancik \& B. Staw (Eds.), New directions in organizational behavior (pp. 4762). New York: St. Clair Press.

Carnevale, P. J. D., Pruitt, D. G., \& Britton, S. D. (1979). Looking tough: The negotiator under constituent surveillance. Personality and Social Psychology Bulletin, 5, 118-121.

Carver, C. S. (1979). A cybernetic model of self-attention processes. Journal of Personality and Social Psychology, 37, 1251-1281.

Cherry, E. C. (1953). Some experiments on the recognition of speech. with one and with two ears. Journal of the Acoustical Society of America, 25, 975-979.

Christie, R., \& Geis, F. L. (Eds.). (1970). Studies in Machiavellianism. New York: Academic Press.

Cialdini, R. B., Borden, R. J., Thorne, A., Walker, M. R., Freeman, S., \& Sloan, L. R. (1976). Basking in reflected glory: Three (football) field studies. Journal of Personality and Social Psychology, 34, 366375.

Cialdini, R. B., \& Richardson, K. D. (1980). Two indirect tactics of image management: Basking and blasting. Journal of Personality and Social Psychology, 39, 406-415.

Cooley, C. H. (1902). Human nature and the social order. New York: Scribner's.

Cozby, P. C. (1973). Self-disclosure: A literature review. Psychological Bulletin, 79, 73-91.

Crowne, D. P., \& Marlowe, D. (1964). The approval motive: Studies in evaluative dependence. New York: Wiley.

Darley, J. M., \& Goethals, G. R. (1980). People's analyses of the causes of ability-linked performances. In L. Berkowitz (Ed.), Advances in experimental social psychology (Vol. 13, pp. 1-37). New York: Academic Press.

Dean, D. G., Braito, R., Powers, E. A., \& Britton, B. (1975). Cultural contradictions and sex roles revisited: $A$ replication and a reassessment. The Sociological Quarterly, 16, 201-215.

Deaux, K., \& Major, B. (1987). Putting gender into context: An interactive model of gender-related behavior. Psychological Review, 94, 369 389.

DePaulo, B. M., Kenny, D. A., Hoover, C. W., Webb, W., \& Oliver, P. V. 
(1987). Accuracy of person perception: Do people know what kinds of impressions they convey? Journal of Personality and Social Psychology, 52, 303-315.

DePaulo, B. M., Stone, J. I., \& Lassiter, G. D. (1985). Deceiving and detecting deceit. In B. R. Schlenker (Ed.), The self and social life (pp. 323-370). New York: McGraw-Hill.

Diener, E. (1979). Deindividuation, self-awareness, and disinhibition. Journal of Personality and Social Psychology, 37, 1160-1171.

Dies, R. (1970). Need for social approval and blame assignment. Journal of Consulting and Clinical Psychology, 35, 311-316.

Duval, S., \& Wicklund, R. A. (1972). A theory of objective self-awareness. New York: Academic Press.

Elliott, G. C. (1979). Some effects of deception and level of self-monitoring on planning and reacting to self-presentation. Journal of Personality and Social Psychology, 37, 1282-1292.

Felson, R. B. (1978). Aggression as impression management. Social Psychology Quarterly, 41, 205-213.

Fenigstein, A. (1987). On the nature of public and private self-consciousness. Journal of Personality, 55, 543-554.

Festinger, L. (1957). A theory of cognitive dissonance. Stanford, CA: Stanford University Press.

Festinger, L., \& Carlsmith, J. M. (1959). Cognitive consequences of forced compliance. Journal of Abnormal and Social Psychology, 58, 203-210.

Filter, T. A., \& Gross, A. E. (1975). Effects of public and private deviancy on compliance with a request. Journal of Experimental Social Psychology, 11, 553-559.

Fontana, A. F. (1971). Machiavellianism and manipulation in the mental patient role. Journal of Personality, 39, 252-263.

Forsyth, D. R., Riess, M., \& Schlenker, B. R. (1977). Impression-management concerns governing reactions to a faulty decision. Representative Research in Social Psychology, 8, 12-22.

Frey, D. (1978). Reactions to success and failure in public and in private conditions. Journal of Experimental Social Psychology, 14, 172-179.

Friedlander, M. L., \& Schwartz, G. S. (1985). Toward a theory of strategic self-presentation in counseling and psychotherapy. Journal of Counseling Psychology, 32, 483-501.

Gaes, G. G., Kalle, R. J., \& Tedeschi, J. T. (1978). Impression management in the forced compliance situation: Two studies using the bogus pipeline. Journal of Experimental Social Psychology, 14, 493-510.

Gaes, G. G., \& Tedeschi, J. T. (1978). An evaluation of self-esteem and impression management theories of anticipatory belief change. Journal of Experimental Social Psychology, 14, 579-587.

Gergen, K. J. (1965). The effects of interaction goals and personalistic feedback on the presentation of self. Journal of Personality and Social Psychology, 1, 413-424.

Gergen, K. J. (1968). Personal consistency and the presentation of self. In C. Gordon \& K. J. Gergen (Eds.), The self in social interaction (Vol. 1, pp. 299-308). New York: Wiley.

Gergen, K. J., \& Taylor, M. G. (1969). Social expectancy and self-presentation in a status hierarchy. Journal of Experimental Social Psychology, 5, 79-92.

Gergen, K. J., \& Wishnov, V. B. (1965). Others' self-evaluation and interaction anticipation as determinants of self-presentation. Journal of Personality and Social Psychology, 2, 348-358.

Goffman, E. (1955). On facework. Psychiatry, 18, 213-231.

Goffman, E. (1959). The presentation of self in everyday life. Garden City, NY: Doubleday Anchor.

Goffman, E. (1967). Interaction ritual. Garden City, NY: Doubleday Anchor.

Gollwitzer, P. M. (1986). Striving for specific identities: The social reality of self-symbolizing. In R. F. Baumeister (Ed.), Public self and private self(pp. 143-160). New York: Springer-Verlag.

Gove, W. R., Hughes, M., \& Geerken, M. R. (1980). Playing dumb: A form of impression management with undesirable side effects. Social Psychology Quarterly, 43, 89-102.

Greenberg, J., Pyszczynski, J., \& Paisley, C. (1984). The effect of extrinsic incentives on the use of test anxiety as an attributional defense: Playing it cool when the stakes are high. Journal of Personality and Social Psychology, 47, 1136-1145.

Greenwald, A. G. (1982). Ego task analysis: An integration of research on ego-involvement and awareness. In A. H. Hastorf \& A. M. Isen (Eds.), Cognitive social psychology (pp. 109-147). New York: Elsevier/North-Holland.

Greenwald, A. G., \& Breckler, S. J. (1985). To whom is the self presented? In B. R. Schlenker (Ed.), The self and social life (pp. 126145). New York: McGraw-Hill.

Hardy, C. J., Hall, E. G., \& Prestholdt, P. H. (1986). The mediational role of social influence in the perception of exertion. Journal of Sport Psychology, 8, 88-104.

Hendricks, M., \& Brickman, P. (1974). Effects of status and knowledgeability of audience on self-presentation. Sociometry, 37, 440-449.

Henley, N. M. (1977). Body politics: Power, sex, and nonverbal communication. Englewood Cliffs, NJ: Prentice-Hall.

Hogan, R. (1982). A socioanalytic theory of personality. In M. Page (Ed.), Nebraska Symposium on Motivation (pp. 55-89). Lincoln: University of Nebraska Press.

Hogan, R., Jones, W. H., \& Cheek, J. M. (1985). Socioanalytic theory: An alternative to armadillo psychology. In B. R. Schlenker (Ed.), The self and social life (pp. 175-198). New York: McGraw-Hill.

Hollander, E. P. (1958). Conformity, status, and idiosyncrasy credit. Psychological Review, 65, 117-127.

House, W. C. (1980). Effects of knowledge that attributions will be observed by others. Journal of Research in Personality, 14, 528-545.

Hull, C. L. (1943). Principles of behavior. New York: Appleton-CenturyCrofts.

Jellison, J. M., \& Gentry, K. W. (1978). A self-presentation interpretation of the seeking of approval. Personality and Social Psychology Bulletin, 4, 227-230.

Jones, E. E. (1964). Ingratiation. New York: Appleton-Century Crofts.

Jones, E. E., Berglas, S., Rhodewalt, F., \& Skelton, J. R. (1981). Effects of strategic self-presentation on subsequent self-esteem. Journal of Personality and Social Psychology, 41, 407-421.

Jones, E. E., Gergen, K. J., \& Davis, K. E. (1962). Some determinants of reactions to being approved or disapproved as a person. Psychological Monographs, 76 (2, Whole No. 521).

Jones, E. E., Gergen, K. J., Gumpert, P., \& Thibaut, J. W. (1965). Some conditions affecting the use of ingratiation to influence performance evaluation. Journal of Personality and Social Psychology, 1, 613-625.

Jones, E. E., Gergen, K. J., \& Jones, R. G. (1963). Tactics of ingratiation among leaders and subordinates in a status hierarchy. Psychological Monographs, 77 (3, Whole No. 566).

Jones, E. E., \& Pittman, T. S. (1982). Toward a general theory of strategic self-presentation. In J. Suls (Ed.), Psychological perspectives on the self(Vol. 1, pp. 231-262). Hillsdale, NJ: Erlbaum.

Jones, E. E., \& Wortman, C. (1972). Ingratiation: An attributional approach. Morristown, NJ: General Learning Press.

Jones, R. G., \& Jones, E. E. (1964). Optimum conformity as an ingratiation tactic. Journal of Personality, 32, 436-458.

Jones, S. C. (1973). Self and interpersonal evaluations: Esteem theories vs. consistency theories. Psychological Bulletin, 79, 185-199.

Jones, S. C., \& Tager, R. (1972). Exposure to others, need for social approval, and reactions to agreement and disagreement from others. Journal of Social Psychology, 86, 111-120.

Kolditz, T. A., \& Arkin, R. M. (1982). An impression management interpretation of the self-handicapping strategy. Journal of Personality and Social Psychology, 43, 492-502.

Korda, M. (1975). Power. New York: Ballantine Books. 
Kowalski, R. M., \& Leary, M. R. (in press). Strategic self-presentation and the avoidance of aversive events: Antecedents and consequences of self-enhancement and self-depreciation. Journal of Experimental Social Psychology.

Leary, M. R. (1983), Understanding social anxiety. Beverly Hills, CA: Sage.

Leary, M. R. (1989). Self-presentational processes in leadership emergence and effectiveness. In R. A. Giacalone \& P. Rosenfeld (Ed.), Impression management in the organization. Hillsdale, NJ: Erlbaum.

Leary, M. R., Barnes, B. D., \& Griebel, C. (1986). Cognitive, affective, and attributional effects of potential threats to self-esteem. Journal of Social and Clinical Psychology, 4, 461-474.

Leary, M. R., Barnes, B. D., Griebel, C., Mason, E., \& McCormack, D. (1987). The impact of conjoint threats to social- and self-esteem on evaluation apprehension. Social Psychology Quarterly, 50, 304-311.

Leary, M. R., \& Forsyth, D. R. (1987). Attributions of responsibility for collective endeavors. In C. Hendrick (Ed.), Review of personality and social psychology (pp. 167-188). Newbury Park, CA: Sage.

Leary, M. R., Knight, P. D., \& Johnson, K. A. (1987), Social anxiety and dyadic conversation: A verbal response analysis. Journal of Social and Clinical Psychology, 5, 34-50.

Leary, M. R., \& Lamphere, R. (1988). Exchusionary self-presentation in a self-presentational dilemma: Effects of incongruency between selfperceptions and target values. Unpublished manuscript.

Leary, M. R., Robertson, R. B., Barnes, B. D., \& Miller, R. S. (1986). Self-presentations of small group leaders: Effects of role requirements and leadership orientation. Journal of Personality and Social Psychology, 5I, 742-748.

Leary, M. R., \& Schlenker, B. R. (1980). Self-presentation in a taskoriented leadership situation. Representative Research in Social Psychology, 11, 152-158.

Lindskold, S., \& Propst, L. R. (1981). Deindividuation, self-awareness, and impression management. In J. T. Tedeschi (Ed.), Impression management theory and social psychological research (pp. 201-221). New York: Academic Press.

Markus, H., \& Nurius, P. (1986). Possible selves. American Psychologist. 41, 954-969.

Mead, G. H. (1934). Mind, self, and society. Chicago: University of Chicago Press.

Miller, G. A., Galanter, E., \& Pribram, K. H. (1960). Plans and the siructure of behavior. New York: Holt, Rinehart \& Winston.

Miller, L. C., \& Cox, C. L. (1982). For appearance's sake: Public selfconsciousness and make-up use. Personality and Social Psychology Bulletin, 8, 748-751.

Miller, R. S. (1986). Embarrassment: Causes and consequences. In W. H. Jones, J. M. Cheek, \& S. R. Briggs (Eds.), Shyness: Perspectives on research and treatment (pp. 295-311). New York: Plenum Press.

Millham, J., \& Kellogg, R. W. (1980). Need for social approval: Impression management or self-deception? Journal of Research in Personality, $14,445-457$.

Modigliani, A. (1971). Embarrassment, facework, and eye contact: Testing a theory of embarrassment. Journal of Personality and Social Psychology, 17, 15-24.

Mori, D., Chaiken, S., \& Pliner, P. (1987). "Eating lightly" and the selfpresentation of femininity. Journal of Personality and Social Psychology, 53,693-702.

Ogilvie, D. M. (1987). The undesired self: A neglected variable in personality research. Journal of Personality and Social Psychology, 52, 379-385.

Pandey, J. (1981). A note on social power through ingratiation among workers. Journal of Occupational Psychology, 54, 65-67.

Pandey, J. (1986). Sociocultural perspectives on ingratiation. In B. Maher (Ed.), Progress in experimental personality research (Vol. 14, pp. 205-229). New York: Academic Press.
Pandey, J., \& Rastagi, R. (1979). Machiavellianism and ingratiation. Journal of Social Psychology, 108, 221-225.

Piliavin, J. A. (1976). On feminine self-presentation in groups. In J. I Roberts (Ed.), Beyond intellectual sexism (pp. 138-159). New York: David McKay.

Quattrone, G. A., \& Jones, E. E. (1978). Selective self-disclosure with and without correspondent performance. Journal of Experimental Social Psychology, 14, 511-526.

Reis, H. T., \& Gruzen, J. (1976). On mediating equity, equality, and self-interest: The role of self-presentation in social exchange. Journal of Experimental Social Psychology, 12, 487-503.

Reiss, M. (1982). Seating preferences as impression management: A literature review and theoretical integration. Communication, $11,85-$ 113.

Rhodewalt, F. T. (1986). Self-presentation and the phenomenal self: On the stability and malleability of self-conceptions. In R. F. Baumeister (Ed.), Public self and private self (pp. 117-142). New York: SpringerVerlag.

Rogers, C. R. (1959). A theory of therapy, personality and interpersonal relationships, as developed in the client-centered framework. In S. Koch (Ed.), Psychology: A study of a science (Vol. 3, pp. 184-256). New York: McGraw-Hill.

Rosenberg, M. J. (1979). Conceiving the self. New York: Basic Books.

Rosenfeld, H. M. (1966). Approval-seeking and approval-inducing functions of verbal and nonverbal responses in the dyad. Journal of Personality and Social Psychology, 4, 597-605.

Rosenfeld, P., Melburg, V., \& Tedeschi, J. T. (1981). Forgetting as an impression management strategy in the forced-compliance situation. Journal of Experimental Social Psychology, 20, 312-322.

Sanders, G. S. (1984). Self-presentation and drive in social facilitation. Journal of Experimental Social Psychology, 20, 312-322.

Sarbin, T. R., \& Allen, V. L. (1968). Role theory. In G. Lindzey \& E. Aronson (Eds.), The handbook of social psychology (3rd ed., Vol. 1, pp. 488-567). Reading, MA: Addison-Wesley.

Schlenker, B. R. (1975). Self-presentation: Managing the impression of consistency when reality interferes with self-enhancement. Journal of Personality and Social Psychology, 32, 1030-1037.

Schlenker, B. R. (1980). Impression management: The self-concept, social identity, and interpersonal relations. Monterey, CA: Brooks/Cole.

Schlenker, B. R. (1985). Identity and self-identification. In B. R. Schlenker (Ed), The self and social life (pp. 65-99). New York: McGraw-Hill

Schlenker, B. R. (1986). Self-identification: Toward an integration of the private and public self. In R. F. Baumeister (Ed.), Public self and private self (pp. 21-62). New York: Springer-Verlag.

Schlenker, B. R., \& Darby, B. W. (1981). The use of apologies in social predicaments. Social Psychology Quarterly, 44, 271-278.

Schlenker, B. R., Forsyth, D. R., Leary, M. R., \& Miller, R. S. (1980). A self-presentational analysis of the effects of incentives on attitude change following counterattitudinal behavior. Journal of Personality and Social Psychology, 39, 553-577.

Schlenker, B. R., \& Leary, M. R. (1982a). Audiences' reactions to selfenhancing, self-denigrating, and accurate self-presentations. Journal of Experimental Social Psychology 18, 89-104.

Schlenker, B. R., \& Leary, M. R. (1982b). Social anxiety and self-presentation: A conceptualization and model. Psychological Bulletin, 92 , 641-669.

Schneider, D. J. (1969). Tactical self-presentation after success and failure. Journal of Personality and Social Psychology, 13, 262-268.

Schneider, D. J. (1981). Tactical self-presentations: Toward a broader conception. In J. T. Tedeschi (Ed.), Impression management theory and social psychological research (pp. 23-40). New York: Academic Press.

Schneider, D. J., \& Eustis, A. C. (1972). Effects of ingratiation motiva- 
tion, target positiveness, and revealingness on self-presentation. Journal of Personality and Social Psychology, 22, 149-155.

Schneider, D. J., \& Turkat, D. (1975). Self-presentation following success and failure: Defensive self-esteem models. Journal of Personality, 43, 127-135.

Schneider, W., \& Shiffrin, R. M. (1977). Controlled and automatic human information processing: I. Detection, search, and attention. Psychological Review, 84, 1-66.

Shaw, M. E., \& Costanzo, P. R. (1982). Theories of social psychology (2nd ed.). New York: McGraw-Hill.

Shaw, M. E., \& Wagner, P. J. (1975). Role selection in the service of selfpresentation. Memory \& Cognition, 3, 481-484.

Snyder, C. R., Stucky, R. J., \& Higgins, R. L. (1983). Excuses: Masquerades in search of grace. New York: Wiley-Interscience.

Stires, L. D., \& Jones, E. E. (1969). Modesty vs. self-enhancement as alternative forms of ingratiation. Journal of Experimental Social Psychology, 5, 172-188.

Swann, W. B., Jr. (1987). Identity negotiation: Where two roads meet. Journal of Personality and Social Psychology, 53, 1038-1051.

Tedeschi, J. T. (Ed.). (1981). Impression management theory and social psychological research. New York: Academic Press.

Tedeschi, J. T. (1986). Private and public experiences and the self. In R. F. Baumeister (Ed.), Public self and private self (pp. 1-20). New York: Springer-Verlag.

Tedeschi, J. T., Schlenker, B. R., \& Bonoma, T. V. (1971). Cognitive dissonance: Private ratiocination or public spectacle? American Psychologist, 26, 685-695.
Tedeschi, J. T., Smith, R. B., III, \& Brown, R. C., Jr. (1974). A reinterpretation of research on aggression. Psychological Bulletin. 81, 540563.

Tetlock, P. D., \& Manstead, A. S. R. (1985). Impression management vs. intrapsychic explanations in social psychology: A useful dichotomy? Psychological Review, 92, 59-77.

Tunnell, G. (1984). The discrepancy between private and public selves: Public self-consciousness and its correlates. Journal of Personality Assessment, 48, 549-555.

von Baeyer, C. L., Sherk, D. L., \& Zanna, M. P. (1981). Impression management in the job interview: When the female applicant meets the male (chauvinist) interviewer. Personality and Social Psychology Bulletin, 7, 45-51.

Weary, G., \& Arkin, R. M. (1981). Attributional self-presentation. In J. H. Harvey, W. J. Ickes, \& R. I. Kidd (Eds.), New directions in attribution research (Vol. 3, pp. 223-246). Hillsdale, NJ: Erlbaum.

Wicklund, R. A., \& Gollwitzer, P. M. (1982). Symbolic self-completion. Hillsdale, NJ: Erlbaum.

Wicklund, R. A., \& Gollwitzer, P. M. (1987). The fallacy of the privatepublic self-focus distinction. Journal of Personality, 55, 491-523.

Zanna, M. P., \& Pack, S. J. (1975). On the self-fulfilling nature of apparent sex differences in behavior. Journal of Experimental Social Psychology, 11, 583-591.

Received March 2, 1988

Revision received November 18,1988 Accepted November 23, 1988

\section{Beutler, Levin, Tesser, and Miller Appointed New Editors, 1991-1996}

The Publications and Communications Board of the American Psychological Association announces the appointments of Larry E. Beutler, University of Arizona; Joel R. Levin, University of Wisconsin; Abraham Tesser, University of Georgia; and Norman Miller, University of Southern California, as editors of the Journal of Consulting and Clinical Psychology, the Journal of Educational Psychology, the Attitudes and Social Cognition section and the Interpersonal Relations and Group Processes section of the Journal of Personality and Social Psychology, respectively. As of January 1, 1990, manuscripts should be directed as follows:

- For Consulting and Clinical send manuscripts to Larry E. Beutler, Journal of Consulting and Clinical Psychology, Department of Psychiatry, University of Arizona, College of Medicine, Tucson, Arizona 85724.

- For Educational send manuscripts to Joel R. Levin, Department of Educational Psychology, University of Wisconsin, 1025 West Johnson Street, Madison, Wisconsin 53706.

- For JPSP: Attitudes send manuscripts to Abraham Tesser, Institute for Behavioral Research, University of Georgia, 548 Boyd Graduate Studies, D. W. Brooks Drive, Athens, Georgia 30602.

- For JPSP: Interpersonal send manuscripts to Norman Miller, Department of Psychology, Seeley G. Mudd Building, University of Southern California, University Park, Los Angeles, California 90089.

Manuscript submission patterns make the precise date of completion of 1990 volumes uncertain. Current editors will receive and consider manuscripts until December 1989. Should any 1990 volume be completed before that date, manuscripts will be redirected to the newly appointed editor-elect for consideration in the 1991 volume. 